\title{
Monitoring the impact of microbial processes on the fate of hydrocarbons and metals in a Niger Delta soil contaminated with crude oil
}

\author{
RAKIYA AHMAD MUHAMMAD ${ }^{1 *}$, CHRIS BOOTHMAN ${ }^{1}$, \\ JON LLOYD ${ }^{1}$ AND BART VAN DONGEN ${ }^{1}$ \\ ${ }^{1}$ Department of Earth and Environmental Sciences, University \\ of Manchester, UK. \\ (*correspondence:rakiya.muhammadahmad@postgrad.manch \\ ester.ac.uk).
}

Oil spills in Nigeria has severely damaged the Niger Delta ecosystem for over 5 decades [1] and the toxic effect of oil contamination affects the structure and diversity of viable microbial populations [2]. However, the impact of oil conatmination on microbial communty/diversity at depth and how inherent microbes can degrade the pollutants remains unclear.

In the present study the impact of a recent land oil spill on the microbial commuties in soil from Ukpeliede community in the Niger delta was determined. Geochemical analyses of soils/sediments from the contaminated area indicated the presence of hydrocarbon contamination up to $1 \mathrm{~m}$ depth as well as an increased metal contamination originating from the oil. Impacts of the contamination were also clearly observed in the microbial abundance, with diverstiy exhibiting an overall increasing trend with depth and a dominace of Gammaproteo-, Deltaproteo- and Acido bacteria in the most contaminted sediments. Initial microcosm experiment using the contaminated soils showed reduction in the amount of hydrocarbons present particularly in those under anaerobic conditon with the addition of nitrate or sulfate as electron acceptors. Interestingly, a corresponding release of iron in to the water phase was observed while other toxic metals such as chromiun or nickel were not mobilised. Planned microbial anlyses will help us to better understand the impact on the microbial community and the correlation with oil degradation in these microcosm experiments.

[1] Unep. (2011). Environmental Assessment of Ogoniland. https://doi.org/10.3370/lca.2.73. [2] Ruben, G., Oksana, K., Chen, S., Einav, M., Tirza, D., and Yosef, S. (2018). Impact of Oil-Spill Contamination on a Soil Bacterial Community: A 40-Year History of Rehabilitation in the Arava Valley, Soil and Sediment Contamination: $A n$ International Journal, 27: 3, 175-185. 